\title{
Overexpression of microRNA-486 affects the proliferation and chemosensitivity of mesothelioma cell lines by targeting PIMI
}

\author{
SILVANA PINELLI ${ }^{1}$, ROSSELLA ALINOVI $^{1}$, DIANA POLI $^{2}$, MASSIMO CORRADI $^{1,3}$, GIORGIO PELOSI $^{4}$, \\ MARCELLO TISEO $^{1,5}$, MATTEO GOLDONI ${ }^{1}$, DELIA CAVALLO ${ }^{2}$ and PAOLA MOZZONI ${ }^{1}$ \\ ${ }^{1}$ Department of Medicine and Surgery, University of Parma, I-43126 Parma; ${ }^{2}$ INAIL Research, \\ Department of Occupational and Environmental Medicine, Epidemiology and Hygiene, Monte Porzio Catone, I-00078 Rome; \\ ${ }^{3}$ Occupational Medicine Unit University Hospital of Parma, I-43126 Parma; ${ }^{4}$ Department of Chemistry, \\ Life Sciences and Environmental Sustainability, University of Parma, I-43124 Parma; \\ ${ }^{5}$ Medical Oncology Unit, University Hospital of Parma, I-43126 Parma, Italy
}

Received December 21, 2020; Accepted April 8, 2021

DOI: $10.3892 / \mathrm{ijmm} .2021 .4950$

\begin{abstract}
Dysregulated levels of microRNAs (miRNAs or miRs), involved in oncogenic pathways, have been proposed to contribute to the aggressiveness of malignant pleural mesothelioma (MPM). Previous studies have highlighted the downregulation of miRNA miR-486-5p in patients with mesothelioma and the introduction of miRNA mimics to restore their reduced or absent functionality in cancer cells is considered an important therapeutic strategy. The aim of the present study was to evaluate the mechanisms through which miRNAs may influence the functions, proliferation and sensitivity to cisplatin of MPM cells. In the present study, a miR-486-5p mimic was transfected into the H2052 and H28 MPM cell lines, and cell viability, proliferation, apoptosis and mitochondrial membrane potential were monitored. miR-486-5p overexpression led to a clear impairment of cell proliferation, targeting $C D K 4$ and attenuating cell cycle progression. In addition, transfection with miR-486-5p mimic negatively regulated the release of inflammatory factors and the expression of Provirus integration site for Moloney murine leukaemia virus 1 (PIM1). The sensitivity of the cells to cisplatin was enhanced by enhancing the apoptotic effects of the drug and impairing mitochondrial function. On the whole, the present study demonstrates that miR-486-5p may play an important role in MPM treatment by targeting multiple pathways involved in tumour development and progression. These activities may be mostly related to the downregulation of PIMI, a crucial regulator of cell survival and proliferation. Furthermore, these results provide support
\end{abstract}

Correspondence to: Dr Paola Mozzoni, Department of Medicine and Surgery, University of Parma, via A. Gramsci 14, I-43126 Parma, Italy

E-mail: paola.mozzoni@unipr.it

Key words: miRNA-486-5p, malignant pleural mesothelioma, $P I M 1, C D K 4$, cisplatin sensitivity for the combined use of miR-486-5p with chemotherapy as a therapeutic strategy for MPM.

\section{Introduction}

Malignant pleural mesothelioma (MPM), resulting from the malignant transformation of pleura mesothelial cells, is an aggressive, therapy-resistant and mostly fatal cancer strongly associated with the presence of asbestos fibres (1-3). Other factors or etiological agents have also been associated with mesothelioma and among these, the fibrous mineral, erionite, radiations and Simian Virus 40 are considered the most noteworthy $(1,2,4-8)$. The global incidence of MPM has increased over the past decade and has been predicted to peak sometime before $2030(1,3)$. The long latency period between asbestos exposure and tumour development implies that multiple, and likely diverse, genetic alterations are required for the malignant transformation of mesothelial cells; however, the genetic and epigenetic events responsible for the development of MPM remain unclear.

Mesothelial cells are relatively undifferentiated and maintain the ability to differentiate into several cell lines. Accordingly, some mesotheliomas have an epithelial morphology, others, termed sarcomatoid, have a spindle cell morphology and others, termed biphasic mesotheliomas, exhibit a combination of the two (9). It has long been known that survival is influenced by the histological subtype: The epithelial variants are less aggressive than the spindle cell variants $(10,11)$. Patients with the disease have a very poor prognosis with a median survival of 4 to 14 months following diagnosis and a reduced quality of life (11-13). Diagnosis often occurs in the advanced stage and the disease is often refractory to conventional therapy. Despite advancements being made in current treatments, the long-term survival rate of patients has not markedly improved and this unsatisfactory clinical outcome emphasizes an urgent need for the development of novel therapeutic approaches to more effectively manage this lethal disease (1-3).

The research of novel diagnostic or therapeutic targets for mesothelioma has included the study of microRNAs (miRNAs 
or miRs) (14-17). miRNAs are small non-coding RNAs, which regulate the expression of targeted genes by directly binding to the 3'-untranslated region (3'-UTR) of mRNAs. This interaction leads to post-transcriptional repression, resulting in reduced levels of the corresponding protein or the cleavage of their RNA. miRNAs can regulate their target genes by imperfect base-pairing to the 3'-UTR; thus, a single miRNA can target several hundred mRNAs. Moreover, a single target gene often includes more binding sites for multiple miRNAs that can bind co-operatively, allowing miRNAs to form a complex regulatory control network (18).

miRNA expression is widely tissue- and cell-type specific. miRNAs function as regulators in a number of cellular processes from basic metabolic maintenance, through differentiation, cell cycle and proliferation, to death and consequently, in tumorigenesis, cancer metastasis and drug resistance (14). A number of miRNAs involved in oncogenic pathways are downregulated in mesothelioma, and this is largely due to chromosomal aberrations. It has thus been hypothesized that the re-expression or the enhanced expression of these miRNAs in mesothelioma cells may influence important functions, such as proliferation, migration, invasion, apoptosis, or chemoresistance $(17)$ and may enhance therapeutic outcomes $(15,16)$. This approach may also be an opportunity to personalise such a treatment for each patient's miRNA tumour profile.

The aberrant expression of miR-486-5p (hereafter referred to as miR-486) has been observed in different types of human cancer (19) such as hepatocellular carcinoma $(20,21)$, lung cancer $(22,23)$, breast cancer $(24)$, oesophageal squamous cell carcinoma (25) and pancreatic cancer (26). Its hypoexpression seems to promote the progression of lung, oesophagus and breast cancer, while it is usually upregulated in pancreatic tumours, chronic myeloid leukemia and gliomas (27). It was therefore proposed and applied as an effective biomarker for the diagnosis, as well as the prognosis of human cancer (27).

In a previous study, the authors aimed to identify a pattern of miRNAs as possible diagnostic and prognostic biomarkers for MPM and asbestosis; all investigated miRNAs, including miR-486, were downregulated in the plasma of patients with respect to the healthy subjects (28). Given the low expression of miR-486 in mesothelioma, it was hypothesized that miR-486 may act as a tumour suppressor, targeting several genes. Out of these genes, particular attention was paid to the Provirus integration site for Moloney murine leukaemia virus 1 (PIM1), for its high expression in human cancers (29-32) and in mesothelioma cell lines (33), and as PIMl is a target of miR-486 $(34,35)$. PIMI is a serine/threonine kinase that acts as protooncogene to mediate cell survival and has been associated with carcinogenesis by promoting tumour cell proliferation and inhibiting apoptosis.

The present study therefore aimed to restore high levels of miR-486 in mesothelioma cell lines by miRNA mimic transfection in order to investigate its regulatory functions and to evaluate the possible effects of its overexpression on cell proliferation, cell cycle, apoptosis and on the modulation of sensitivity to cisplatin (CDDP). CDDP is thus far the only therapy approved against MPM and miR-486 seems to enhance cell sensitivity to this drug (36-38).

\section{Materials and methods}

Cells, cell culture and treatments. The human mesothelioma cell lines, H28 (CRL 5820 lot. 59191373) and H2052 (CRL 5915 lot. 63445445), were obtained from the American Type Culture Collection (ATCC) and maintained as a monolayer culture in the Roswell Park Memorial Institute (RPMI)-1640 nutrient medium supplemented with $10 \%$ foetal bovine serum (Euroclone S.p.A.) at $37^{\circ} \mathrm{C}$ in $5 \% \mathrm{CO}_{2}$ in a humidified air atmosphere. Only cells in the logarithmic phase of growth were used in the experiments and allowed to attach for $24 \mathrm{~h}$ prior to transfection or treatments. For CDDP treatment, cells were incubated with various concentrations of the drug $(0-100 \mu \mathrm{M})$ for 24,48 or $72 \mathrm{~h}$. An untreated sample was used as a control. After establishing the $\mathrm{IC}_{50}$ value for the different lines, this concentration was used in subsequent treatments, where not otherwise indicated.

miRNA transfection. mirVana ${ }^{\mathrm{TM}} \mathrm{miR}-486-\mathrm{mimic}$ and control-mimic were designed and synthesized by Life Technologies; Thermo Fisher Scientific, Inc. Cells were transfected with miR-mimic diluted with Opti-MEM I reduced serum medium (Gibco-Life Technologies; Thermo Fisher Scientific, Inc.) using Lipofectamine 2000 (Invitrogen; Thermo Fisher Scientific, Inc.), according to the manufacturer's protocol, at the final concentrations of 50 or $10 \mathrm{nM}$. Cells were seeded at the number suggested in the manufacturer's protocol for the different plates. After 24,48 or $72 \mathrm{~h}$, total RNA was extracted and the transfection efficiency was verified by reverse transcription-quantitative PCR (RT-qPCR).

RNA extraction. RNA was isolated from the cultured cells using TRIzol reagent (Thermo Fisher Scientific, Inc.) according to the manufacturer's instructions. The extracted RNA was digested using the DNase I (DNA-free kit; Thermo Fisher Scientific, Inc.) to remove any genomic DNA contamination and it was quantified using a NanoDrop spectrophotometer (Thermo Fisher Scientific, Inc.).

miRNA quantification. Total RNA was reverse transcribed using a TaqMan MicroRNA RT kit (Thermo Fisher Scientific, Inc.), according to the manufacturer's instruction. The reaction included $3 \mu \mathrm{l}$ of stem-loop RT primer $50 \mathrm{nM}, 1.5 \mu \mathrm{l}$ of $10 \mathrm{X}$ RT buffer, $0.15 \mu \mathrm{l}$ of dNTPs $100 \mathrm{mM}, 0.19 \mu \mathrm{l}$ RNase Inhibitor $20 \mathrm{U} / \mu 1,1 \mu \mathrm{l}$ of MultiScribe reverse transcriptase $50 \mathrm{U} / \mu \mathrm{l}$ and $5 \mu \mathrm{l}$ of RNA sample in a total volume of $15 \mu \mathrm{l}$. The retrotranscription program included a cycle of $30 \mathrm{~min}$ at $16^{\circ} \mathrm{C}$, a cycle of $30 \mathrm{~min}$ at $42^{\circ} \mathrm{C}$ and a cycle of $5 \mathrm{~min}$ at $85^{\circ} \mathrm{C}$. Quantitative PCR (qPCR) was performed using the QuantStudio 7 Flex Real-Time PCR System (Applied Biosystems; Thermo Fisher Scientific, Inc.). A total of $1.33 \mu 1$ of cDNA solutions were amplified using TaqMan 2X Universal PCR Master Mix (Life Technologies; Thermo Fisher Scientific, Inc.) and TaqMan microRNA assays [(miRNA-486-5p:ID 001268), Thermo Fisher Scientific, Inc.] in $20 \mu \mathrm{l}$ of mixture. The reaction consisted of one step at $95^{\circ} \mathrm{C}$ for $10 \mathrm{~min}$, followed by 40 cycles of $95^{\circ} \mathrm{C}$ for $15 \mathrm{sec}$ and $60^{\circ} \mathrm{C}$ for $1 \mathrm{~min}$. All assays were performed in duplicate, and one no-template and two interpolate controls were used in each experiment. The $\mathrm{Cq}$ values of the target miRNAs were normalized to sno-RNU6B 
[(TaqMan microRNA Assays, ID 001093), Thermo Fisher Scientific, Inc.] and the fold changes in expression of each miRNA were calculated using $2^{-\Delta \Delta C q}$ method (39).

Gene expression. cDNA was synthesized using a commercial kit based on the use of inverse transcriptase, [High-Capacity RNA-to-cDNA ${ }^{\mathrm{TM}}$ kit (Applied Biosystems; Thermo Fisher Scientific, Inc.)], following the manufacturer's recommended experimental conditions. RT-qPCR was performed using the QuantStudio 7 Flex Real-Time PCR System (Thermo Fisher Scientific, Inc.) employing TaqMan 2X Universal PCR Master Mix (Life Technologies; Thermo Fisher Scientific, Inc.) and the following TaqMan gene expression assays (Thermo Fisher Scientific, Inc.): CCND1 (Hs00765553_m1), CCNE1 (Hs01026536_m1), CDK4 (Hs00364847_m1) and PIM1 (Hs01065498_m1). The reactions consisted of one step at $95^{\circ} \mathrm{C}$ for $10 \mathrm{~min}$, followed by 40 cycles of $95^{\circ} \mathrm{C}$ for $15 \mathrm{sec}$ and $60^{\circ} \mathrm{C}$ for $1 \mathrm{~min}$. All assays were performed in duplicate, and one no-template and two interpolate controls were used in each experiment. The expression values of each mRNAs were normalized to the expression of the GAPDH housekeeping gene [(Hs02758991_g1, Thermo Fisher Scientific, Inc.]. The changes in the expression of each mRNA with respect to the untreated controls were calculated using the $2^{-\Delta \Delta \mathrm{Cq}}$ method (39).

Cell viability assay. Cells were seeded in 96-well plates (5,000-10,000 cells/well) and incubated at $37^{\circ} \mathrm{C}$ overnight, and then transfected with miR-486 mimic or negative control miRNA, respectively, according to the manufacturer's protocol (Invitrogen; Thermo Fisher Scientific, Inc.). The proliferation of MPM cells was examined by 3-(4,5-dimethylthiazole)-2, 5-diphenyltetrazoliumbromide (MTT) assay (Sigma-Aldrich; Merck KGaA). At the fixed time points, $10 \mu \mathrm{l}$ of MTT reagent $(5 \mathrm{mg} / \mathrm{ml})$ was added into each well prior to incubation at $37^{\circ} \mathrm{C}$ for $3 \mathrm{~h}$. The reaction was terminated by the addition of $100 \mu \mathrm{l}$ of solubilization solution and the absorbance was recorded using a Multiscan Ascent plate reader (Thermo Labsystems) at a wavelength of $560 \mathrm{~nm}$. The number of viable cells was determined using a calibration curve, consisting of a decreasing number of cells and confirmed by counting viable cells in a haemocytometer (trypan blue exclusion). All measurements were performed at least in triplicate.

Cell cycle analysis. Cells were seeded in 6-well plates ( 200,000 cells/well), transfected and, after 24,48 or $72 \mathrm{~h}$, flow cytometric analysis of the cell cycle phase distribution of cells was performed after staining, overnight at $4^{\circ} \mathrm{C}$, the fixed cells with propidium iodide (PI). At the end of transfection and/or treatments, the cells were collected by trypsinization, washed twice with ice-cold PBS, and fixed with 96\% ethanol overnight at $4^{\circ} \mathrm{C}$. Following fixation, the cells were washed again with PBS, incubated with RNase and PI at $4^{\circ} \mathrm{C}$ overnight prior to flow cytometric analysis. Cell cycle phase distribution was analysed using a FC500 ${ }^{\mathrm{TM}}$ flow cytometer (Beckman Coulter, Inc.) and FlowJo_V10 software (FlowJo, LLC).

Measurement of interleukin (IL-6 release). Immediately after the transfection period, cell culture supernatants were collected and centrifuged at $16,000 \mathrm{x} \mathrm{g}$ for $5 \mathrm{~min}$ at $4^{\circ} \mathrm{C}$ to remove cell debris and particles. The IL- 6 concentrations were measured using commercially available ELISA kits (cat. no. KHC0061, Invitrogen; Thermo Fisher Scientific, Inc.) following the manufacturer's instructions, and were normalized to the number of cells. The concentrations of IL- 6 in the medium from the treated cells were compared to the basal concentrations observed in the untreated cells.

Apoptosis. Annexin V staining was performed for the apoptosis assay. Following transfection and/or treatments, the cells were harvested by trypsinization, washed with cold PBS three times and stained with Annexin V-fluorescein isothiocyanate (FITC), PI in the dark, according to the manufacturer's instructions (Bender MedSystems GmbH). Cells were immediately sorted in a $\mathrm{FC} 500^{\mathrm{TM}}$ flow cytometer (Beckman Coulter, Inc.) and data were analysed using FlowJo_V10 software. The percentages of Annexin V-positive cells were calculated as the cell apoptotic rate.

To evaluate the activity of caspase- 3 , a proluminescent DEVD-aminoluciferin substrate was added to the cell culture, according to the manufacturer's protocol (Promega Corporation). The luminescent signal generated by caspase cleavage, proportional to caspase-3/7 activity, was quantified by means of a Cary Eclipse fluorescence spectrophotometer (Varian, Inc.).

Western blot analysis. Cells were lysed in RIPA buffer (Thermo Fisher Scientific, Inc.), and the proteins contents were quantified using the BCA protein assay kit (Thermo Fisher Scientific, Inc.). $30 \mu \mathrm{g}$ of proteins were separated by $10 \%$ sodium dodecyl sulfate-polyacrylamide gel electrophoresis (SDS-PAGE), then transferred onto nitrocellulose membranes (Schleicher \& Schuell). The membranes were incubated in succession with the blocking buffer (5\% BSA in PBS) for $2 \mathrm{~h}$ at room temperature, with the primary mouse monoclonal antibody anti-PIM1 diluted 1:250 (cat. no. ab54503), rabbit monoclonal antibodies anti-CDK4 diluted 1:1,000 (cat. no. ab108355), anti-cyclin D1 dilute 1:200 (cat. no. ab16663) or anti-cyclin E1 diluted 1:1,000 (cat. no. ab33911) (all from Abcam) overnight at $4^{\circ} \mathrm{C}$ and finally with horseradish-peroxidase conjugated goat anti-mouse diluted 1:200,000 (cat. no. STAR207P; Bio-Rad Laboratories, Inc.) or anti-rabbit IgG secondary antibodies diluted 1:200,000 (cat. no. STAR208P, Bio-Rad Laboratories, Inc.), incubated $2 \mathrm{~h}$ at room temperature. Protein blots were detected using an ECL Chemiluminescent Substrate (Cyanogen) and the intensity of the bands was quantitatively analysed using the Fluor-Sä MultiImager (Bio-Rad Laboratories, Inc.).

JC-1 assay. Mitochondrial membrane potential was evaluated by JC-1 assay (Biotium, Inc.). At the end of the treatment period, all cells were recovered and stained at $37^{\circ} \mathrm{C}$ for $15 \mathrm{~min}$ with the cationic dye according to the manufacturer's instructions. The cell suspension was finally transferred into the wells of a black 96-well plate and the absorbance was recorded using a Cary Eclipse fluorescence microplate reader (Varian, Inc.; red fluorescence: Excitation $550 \mathrm{~nm}$, emissions $600 \mathrm{~nm}$; green fluorescence: Excitation $485 \mathrm{~nm}$, emission $540 \mathrm{~nm}$ ). Hydrogen peroxide was used as a positive control. The ratio of the fluorescence of JC-1 aggregates (red) to monomers (green) was calculated and normalized to the respective control. 
A

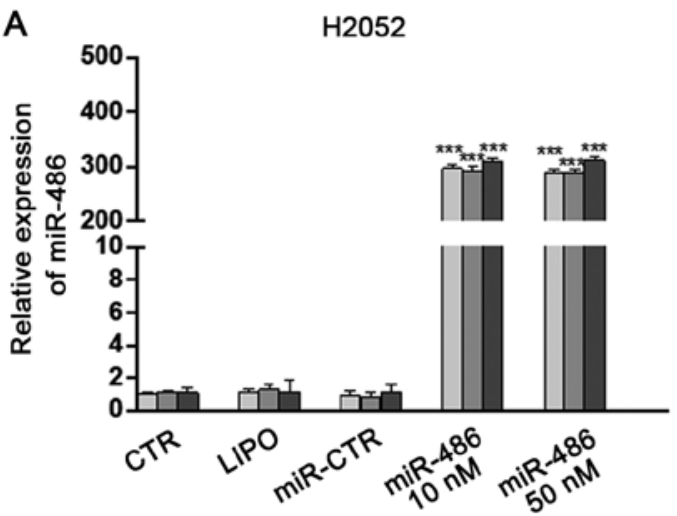

C

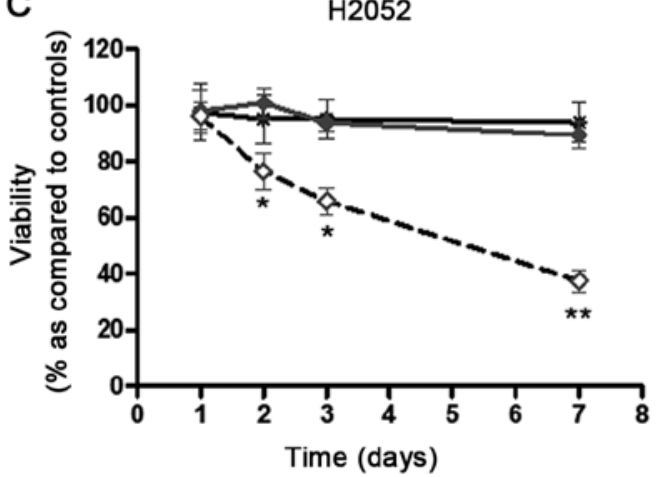

B

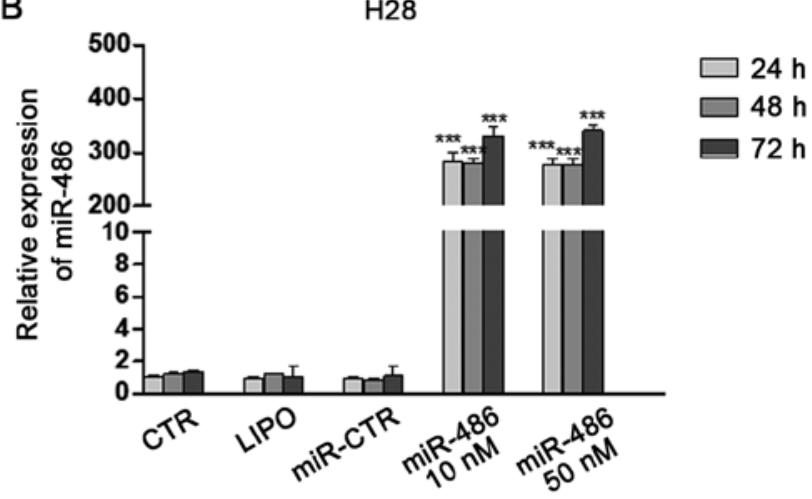

D

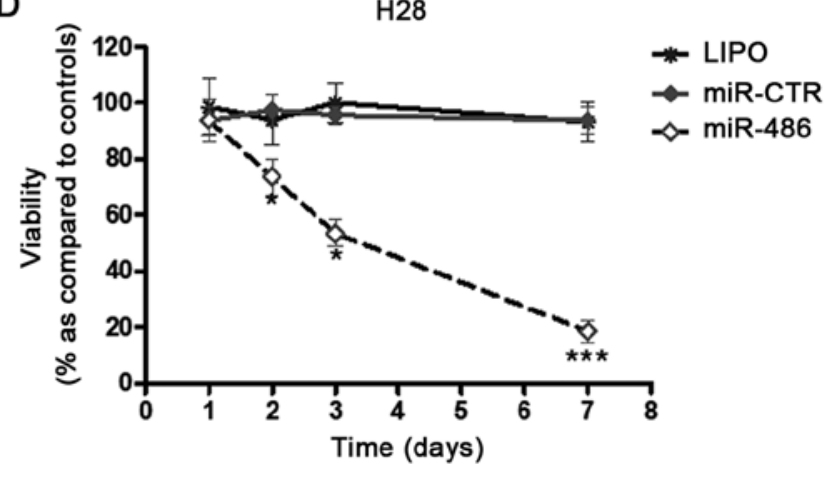

Figure 1. Overexpression of miR-486 reduces cell proliferation. (A and B) Relative expression of miR-486 following transfection of H2052 and H28 cells with miR-486 mimic (up to $72 \mathrm{~h}$ ). (C and D) Cell proliferation following miR-486 induction (10 nM) in H2052 and H28 cells, respectively. CTR, control; LIPO, Lipofectamine; miR-CTR, miRNA control. Each value of cell growth refers to its non-induced condition. Statistical significance is indicated vs. the control: ${ }^{*} \mathrm{P}<0.05 ;{ }^{* *} \mathrm{P}<0.01 ;{ }^{* * *} \mathrm{P}<0.001$.

Oxidative stress. The formation of intracellular reactive oxygen species (ROS) was evaluated by 2,7-dichlorodihydrofluorescein diacetate (DCFH-DA) (Sigma-Aldrich; Merck KGaA): This non-polar and non-fluorescent compound can diffuse into the cytoplasm where it is cleaved by intracellular esterases to yield polar, non-fluorescent 2',7'-dichlorofluorescein (DCF). DCFH can then react with ROS to form a highly fluorescent two-electron oxidation product, DCF. Following miR-486 mimic transfection, the cells were treated for $24 \mathrm{~h}$ with CDDP (17.3 $\mu \mathrm{M}$ for the $\mathrm{H} 2052$ and $50 \mu \mathrm{M}$ for the $\mathrm{H} 28$ cells) and then incubated with $10 \mu \mathrm{M}$ DCFH-DA in PBS at $37^{\circ} \mathrm{C}$ for $30 \mathrm{~min}$ in the dark. Hydrogen peroxide $(10 \mu \mathrm{M})$ was used as a positive control for the assay. Cells were then harvested, washed with PBS and analysed by FC500 ${ }^{\mathrm{TM}}$ flow cytometer (Instrumentation Laboratory) and the FlowJo_V10 software.

Statistical analysis. The results are presented as the mean \pm standard deviation of almost three experiments. Statistical analyses were carried out using ine-way analysis of variance (ANOVA) with Dunnett's or Turkey's post hoc tests. The differences were considered statistically significant with values of $\mathrm{P}<0.05, \mathrm{P}<0.01$ and $\mathrm{P}<0.001$.

\section{Results}

miR-486 expression following transfection. In order to investigate the biological roles of miRNA-486 in the human mesothelioma cell lines, $\mathrm{H} 28$ and H2052, its expression was selectively regulated by $\mathrm{miR}-486$ mimic transfection. Two concentrations of miR mimic were tested: 10 and $50 \mathrm{nM}$. The results of RT-qPCR indicated that in both cell lines, the miRNA was overexpressed in comparison to the controls (untreated, Lipofectamine-treated or miR-control-transfected cells) beginning from $24 \mathrm{~h}$ following transfection. No significant differences were observed between the two concentrations (Fig. 1A and B). For this reason, in the subsequent experiments, the concentration of $10 \mathrm{nM}$ was used.

miR-486 affects cell proliferation, cell cycle progression and $I L-6$ release. $\mathrm{miR}-486$ was transiently transfected into $\mathrm{H} 28$ and H2052 cells. It was observed that miR-486 overexpression led to a reduction in the proliferation of both cell lines (Fig. 1C and D), without significant lysis or apoptosis. This decrease occurred late (48 $\mathrm{h}$ following transfection) and this was time-dependent. In order to evaluate the effects of miR-486 on cell proliferation, the percentage of cells in the different stages of the cell cycle was analysed by flow cytometry. The results revealed that the overexpression of miR-486 significantly reduced cell proliferation and this was mainly reflected by the higher percentage of cells arrested in the G0/G1 phase (Fig. 2). The corresponding proportions of cells in the $\mathrm{S}$ phase and in the $\mathrm{G} 2 / \mathrm{M}$ phase decreased significantly. The absence of a subG0/G1 peak confirmed the absence of a massive apoptotic activation. The expression of cyclins involved in the G1/S transition (CCNE1 and $C C N D 1$ and $C D K 4)$ was also examined. These expression levels significantly decreased in the miR-486 mimic-transfected H28 and H2052 cells, although at different time points and at varying extents (Fig. 3A). In the 
A

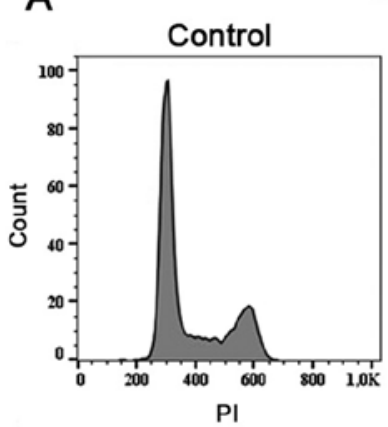

H2052

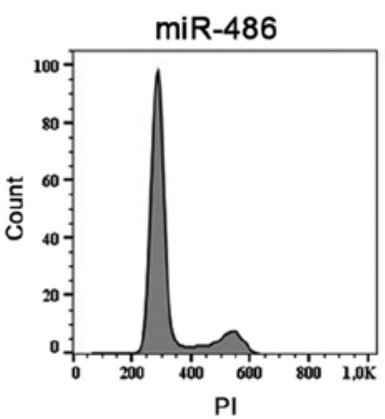

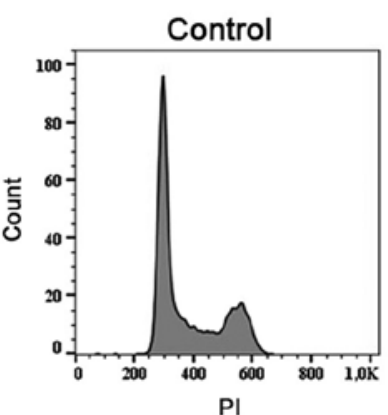

$\mathrm{H} 28$

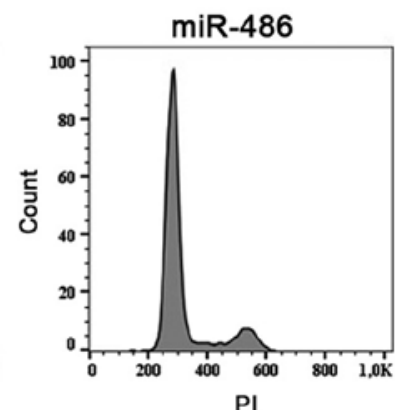

B

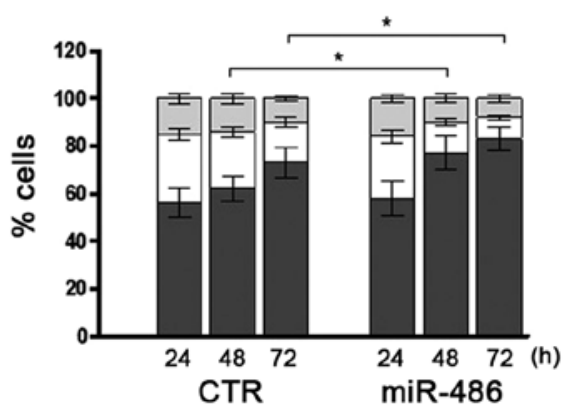

G0/G1

$\mathrm{S}$

G2/M

Figure 2. miR-486 mimic transfection slows cell cycle progression. (A) Flow cytometry histograms of the H2052 and H28 cell cycle following 72 h of transfection. By monoparametric DNA analysis three distinct phases could be recognized: The $G_{0} / G_{1}, S$ and $G_{2} M$ phase. (B) Cell cycle distribution in transfected $\mathrm{H} 2052$ and $\mathrm{H} 28$ cells (up to $72 \mathrm{~h}$ ). Statistical significance is indicated vs. the control: ${ }^{*} \mathrm{P}<0.05$.
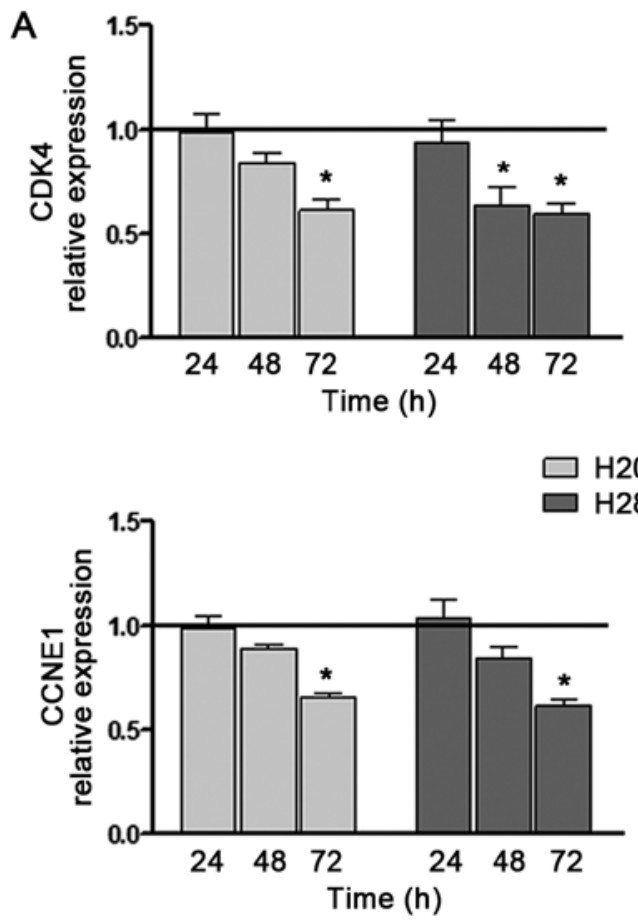

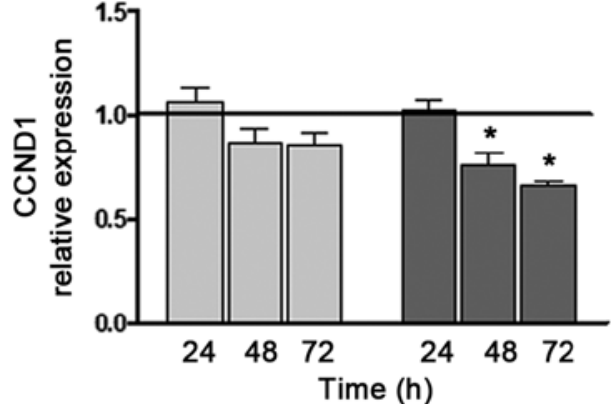

B
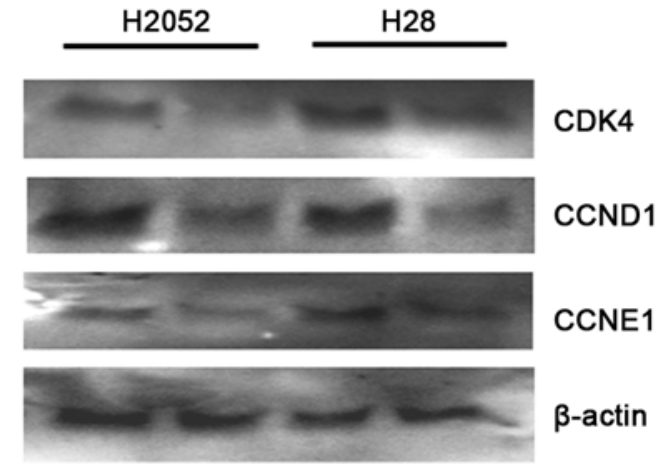

$\operatorname{miR}-486$

Figure 3. miR-486 modulates the expression of cyclins and CDK4. (A) Relative expression of $C D K 4, C C N D 1$ and $C C N E 1$ following transfection with miR-486 mimic. Expression values refer to the control condition (miRNA control=1). Statistical significance is indicated vs. the control: ${ }^{*} \mathrm{P}<0.05$. (B) Western blot analysis of CDK4, CCND1 and CCNE1 in cellular extracts following $72 \mathrm{~h}$ of transfection.

H28 cells, the reduction was observed at an earlier stage, and was more relevant and time-dependent than that observed in the H2052 cells. The same trend was confirmed by western blot analysis (Fig. 3B).
Transfection induced a time-dependent decrease in PIMI expression beginning from $24 \mathrm{~h}$ and reaching maximum significance after $72 \mathrm{~h}$ compared to the untreated control (Fig. 4A). These results were confirmed by western blot 
A

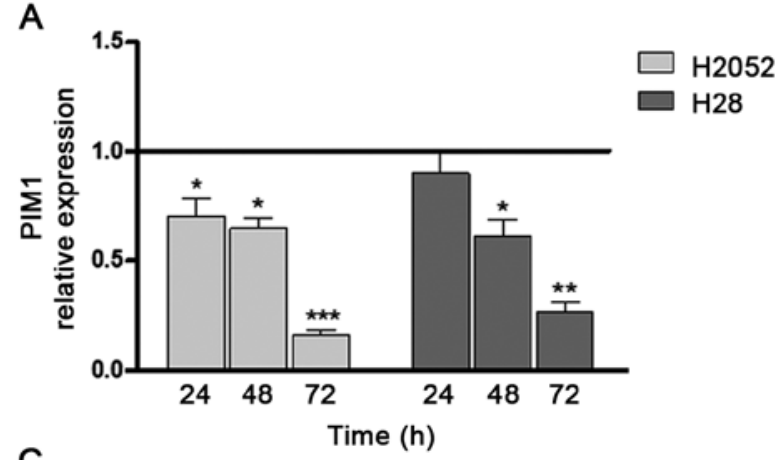

B
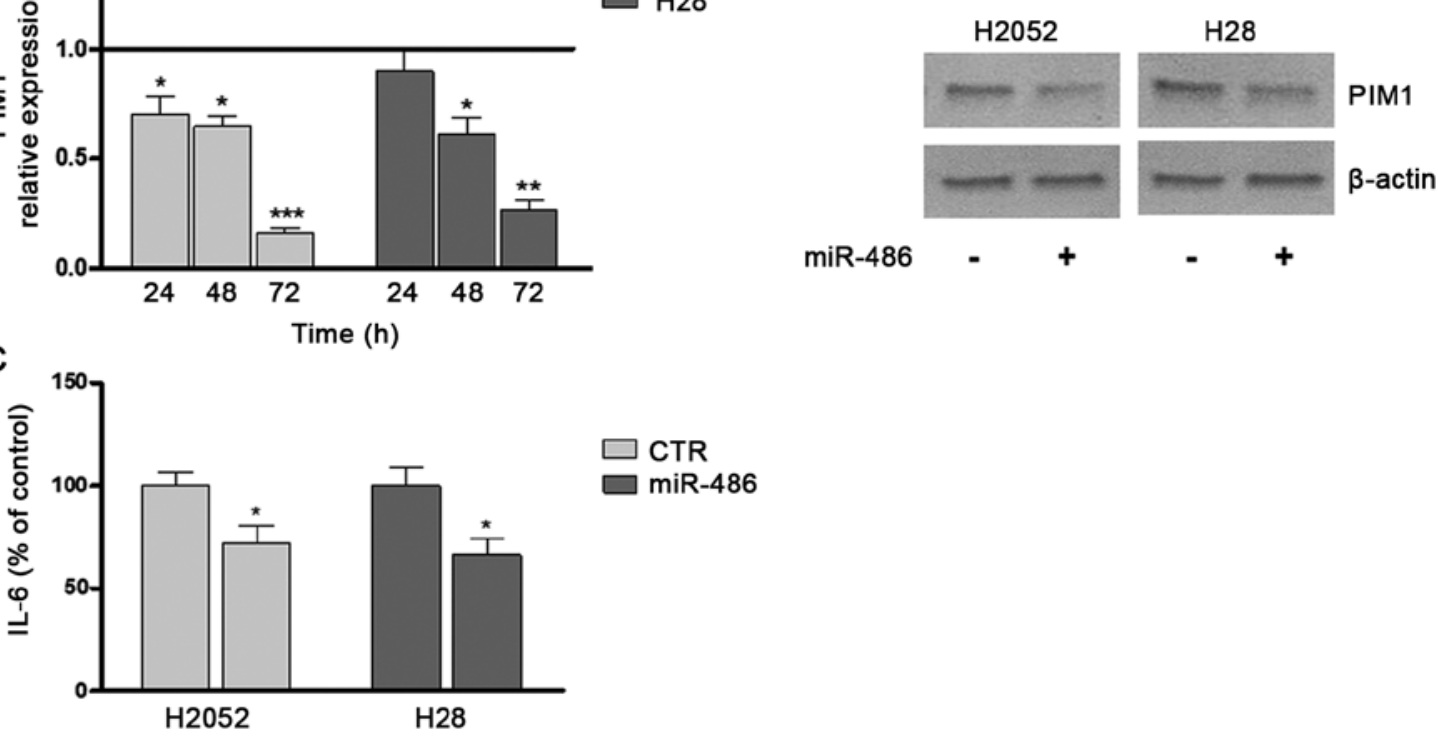

Figure 4. Transfection with miR-486 mimic modulates the expression of PIM1 and the release of inflammation factors. (A) Relative expression of PIMI following transfection. Expression values refer to the control condition (miRNA control=1). (B) Western blot analysis of PIM1 protein following $24 \mathrm{~h}$ of transfection. (C) Concentration of IL-6 in culture medium of transfected cells at $24 \mathrm{~h}$. Comparable results were also obtained 48 and $72 \mathrm{~h}$ post-transfection (data not shown). Values refer to the control condition (miRNA control $=100 \%$ ). Statistical significance is indicated vs. the control: ${ }^{*} \mathrm{P}<0.05$; ${ }^{* *} \mathrm{P}<0.01$; $^{* * * *} \mathrm{P}<0.001$. PIM1, provirus integration site for Moloney murine leukaemia virus 1.

analysis (Fig. 4B). These effects of miR-486 were also coupled with a significant decrease, of approximatively $30 \%$ compared with the controls, in the release of the inflammatory molecule, IL-6, into the culture medium (Fig. 4C).

miR-486 transfection sensitizes MPM cells to CDDP. Treatment of the $\mathrm{H} 28$ and $\mathrm{H} 2052$ cells with various concentrations of CDDP (range, 1-100 $\mu \mathrm{M}$ ) led to a concentration- and time dependent decrease in the viability of both cell lines, although the $\mathrm{H} 2052$ cells were found to be more sensitive than the $\mathrm{H} 28$ cells: At $48 \mathrm{~h}$, the $\mathrm{IC}_{50}$ value for the $\mathrm{H} 2052$ cells was less than half of that for the $\mathrm{H} 28$ cells $(17.83 \mu \mathrm{M}$ vs. $50 \mu \mathrm{M})$. The MPM cells were transfected with miR-486 and then treated with increasing concentrations of CDDP. In both lines, miR-486 reduced viability, beginning from $48 \mathrm{~h}$ following CDDP exposure in comparison to the cells treated with the drug alone (Fig. 5). Correspondingly, significant increases in the numbers of apoptotic cells were observed (Fig. 6A and B) and coupled with the stimulation of caspase- 3 activity (Fig. 6C). In cells transfected with miRNA-486 and treated with CDDP no further decrease in PIMI expression was observed compared with the cells transfected with the mimic only, while it was reduced compared with the cells treated with CDDP alone (Fig. 7). At the same time, an increase in the intracellular ROS levels was observed, and this was particularly significant in the H2052 cells transfected with miRNA-486 end treated with CDDP compared with the control (Fig. 8A). In the H28 cells, ROS accumulation, although present, was lower and not significant compared with the control. At the 24-h time point, the transfected H2052 and H28 cells also exhibited a slight mitochondrial depolarization, as revealed by a decreased $\mathrm{red} / \mathrm{green}$ fluorescence ratio of the membrane-permeant JC-1 dye (Fig. 8B).

\section{Discussion}

As miRNAs are involved in various biological processes in cancer, they are expected to play a crucial role in cancer diagnosis and prognosis surveillance (40). Furthermore, a miRNA-based therapeutic strategy, aimed to restore tumour suppressor miRNA that may be lost or expressed at reduced levels in cancer cells, is expected to constitute a novel potential direction for MPM treatment, particularly for personalized therapy $(41,42)$. To date, at least 20 miRNAs are being evaluated in clinical trials; however, the identification of novel miRNAs is required, not only for therapeutic purposes, but also to understand the mechanisms of oncogenesis and the evolution of tumours (43).

miR-486, which is located in the last intron of the Ankyrin-1 (Ank1) gene on human chromosome 8, was first identified from a human foetal liver cDNA library $(44,45)$. It has been reported to be involved in different types of cancer $(19-25,27,46,47)$ and that its expression is differs markedly between the early and advanced stages of non-small cell lung cancer (NSCLC) (48). Subsequently, a meta-analysis indicated that miR-486 may be used as ideal biomarker for cancer diagnosis, but also concluded that a low expression of this miRNA did not increase the risk of a poor outcome (27).

To date, a few potential targets for miR-486 have been identified (19) and the mechanistic role for miR-486 as either an oncogene or tumour suppressor, particularly in MPM, remains largely unknown. In a previous study (28), the authors aimed at the identification of diagnostic/prognostic biomarkers for asbestos-related diseases; the expression of miRNA-486 was significantly lower in patients with MPM and asbestosis than that in the controls, and this association was significant in plasma and tissues. Furthermore, its tissue expression was 
H2052
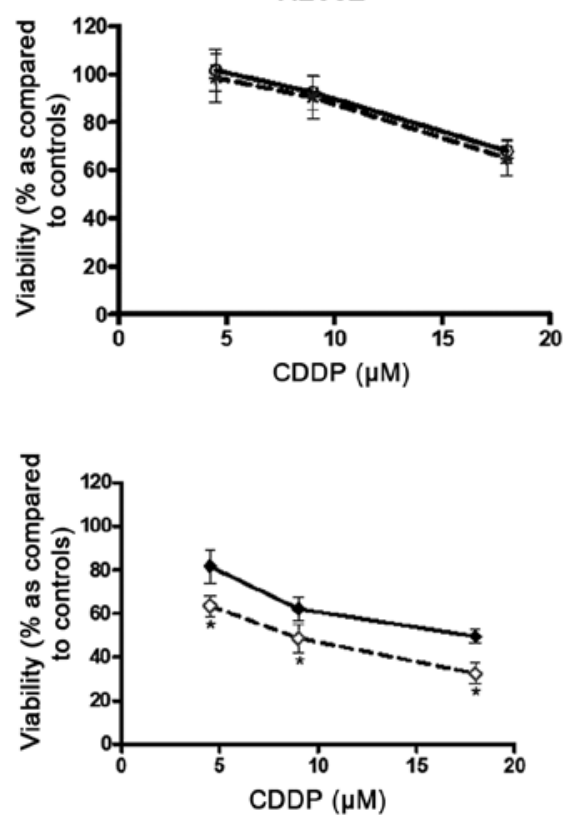

$\mathrm{H} 28$
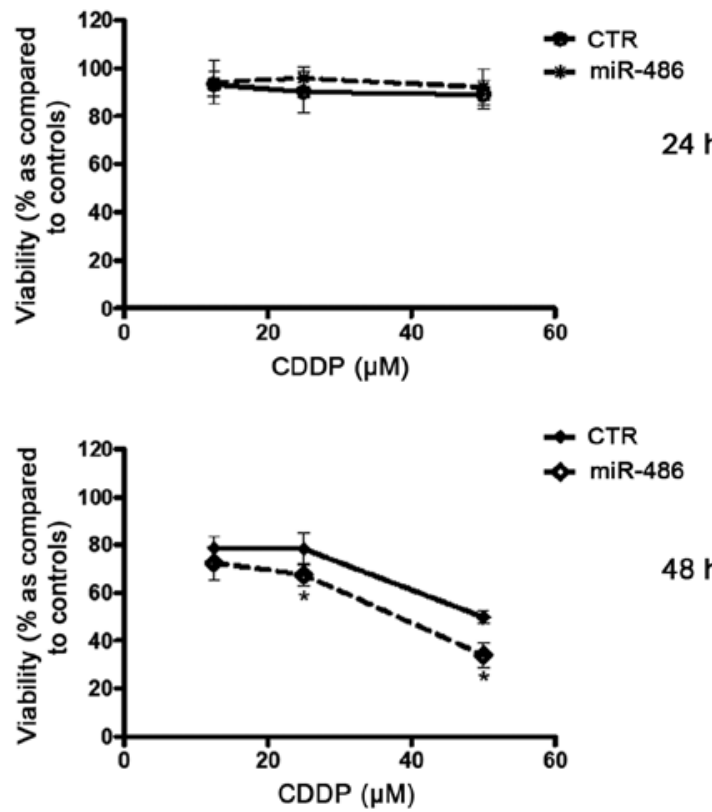

Figure 5. Cytotoxic effects of cisplatin on transfected or non-transfected cells. Exponentially growing $\mathrm{H} 2052$ and $\mathrm{H} 28$ cells were cultured in medium containing increasing concentrations of CDDP. Statistical significance is indicated as follows: CDDP vs. CDDP + miR-486: $\mathrm{P}<0.05$. CDDP, cisplatin.

A

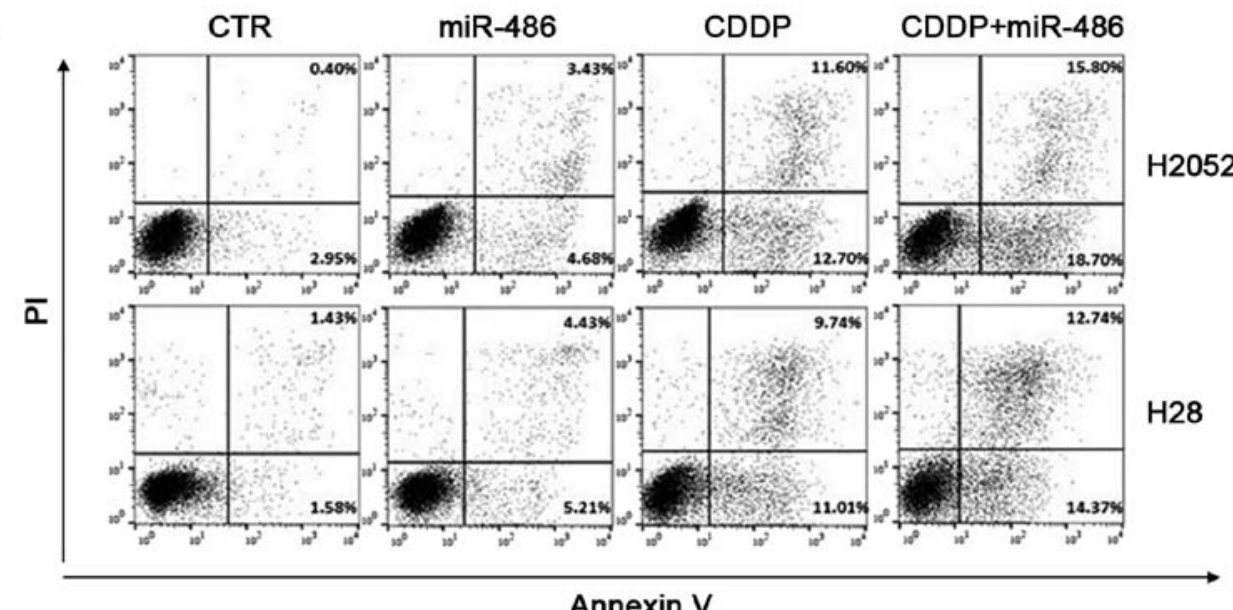

B

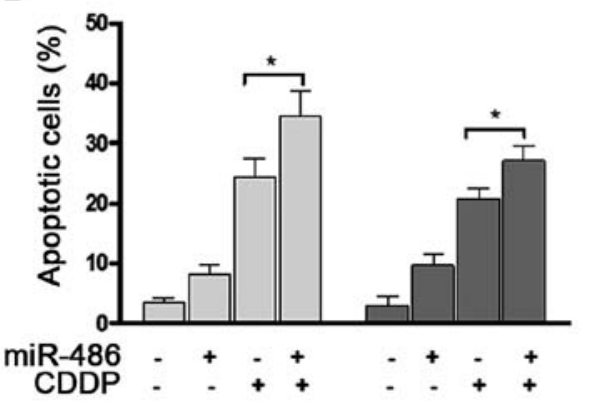

C

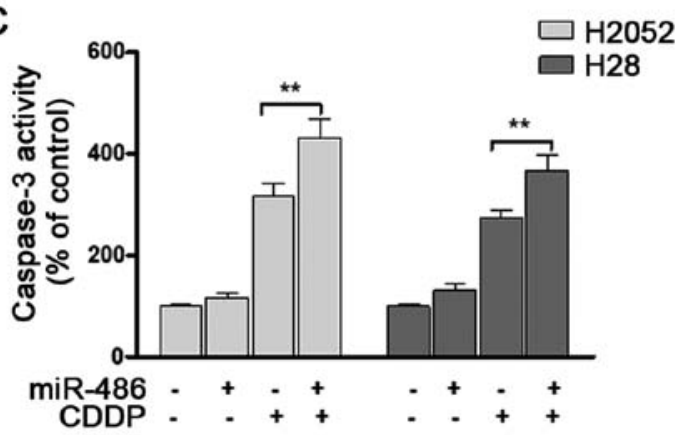

Figure 6. Transfection with miR-486 mimic increases the apoptosis of CDDP-treated cells. Exponentially growing H2052 and H28 cells were transfected and/or treated for $48 \mathrm{~h}$ with $\mathrm{CDDP}$ at the respective $\mathrm{IC}_{50}$ value. (A) Flow cytometry dot plots represent the results of cells staining with Annexin V-FITC/PI. (B) Apoptotic cell percentages. (C) Caspase-3 activity was measured at $24 \mathrm{~h}$ following CDDP treatment. Values refer to the control condition (miRNA control). Statistical significance is indicated as follows: CDDP vs. CDDP + miR-486: ${ }^{*} \mathrm{P}<0.05 ;{ }^{* *} \mathrm{P}<0.01$. CDDP, cisplatin.

positively related to the cumulative survival of patients with MPM. Based on these conclusions, it was hypothesized that miR-486 may play an important role in tumorigenesis and tumour development. Therefore, the present study investigated its potential function by transfecting miR-486 in two in vitro models of MPM. Not surprisingly, it was found that miR-486 
A

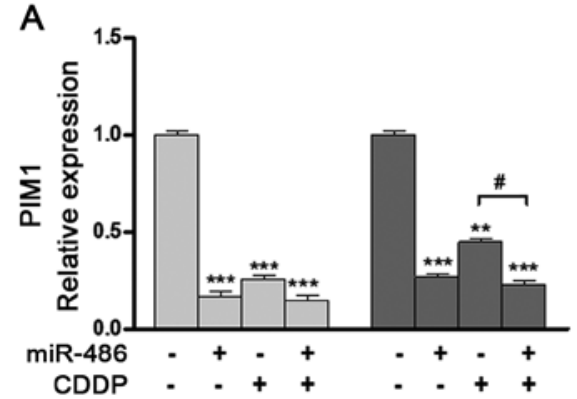

B

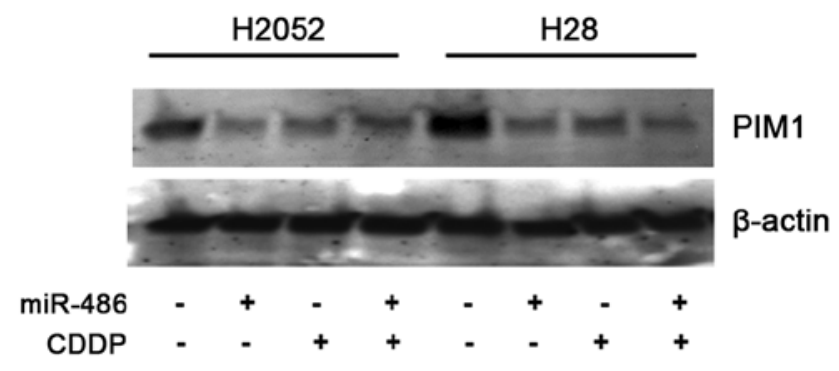

Figure 7. Combined effects of transfection and CDDP treatment on PIM1 expression. (A) Relative expression of PIM1. Expression values refer to the control condition (miRNA control=1). (B) Western blot analysis of PIM1 protein following $24 \mathrm{~h}$ of transfection with miR-486 and/or treatment with CDDP in H2052 and $\mathrm{H} 28$ cells. Values refer to the control condition. Statistical significance is indicated vs. control, ${ }^{* *} \mathrm{P}<0.01 ;{ }^{* * *} \mathrm{P}<0.001 ;$ and vs. the separate treatments, ${ }^{\#} \mathrm{P}<0.05$. PIM1, Provirus integration site for Moloney murine leukaemia virus 1; CDDP, cisplatin.

A

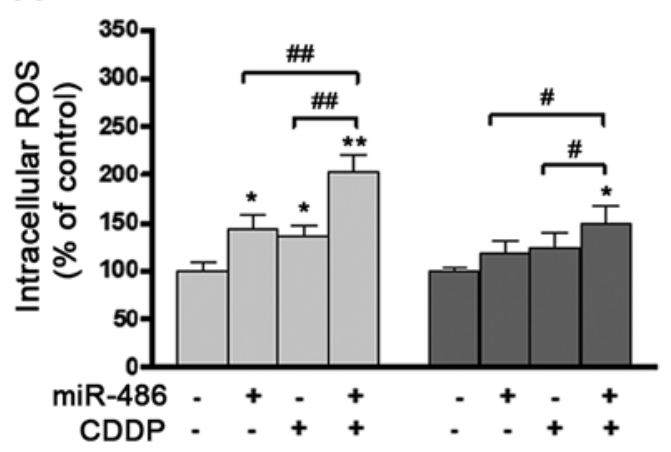

B

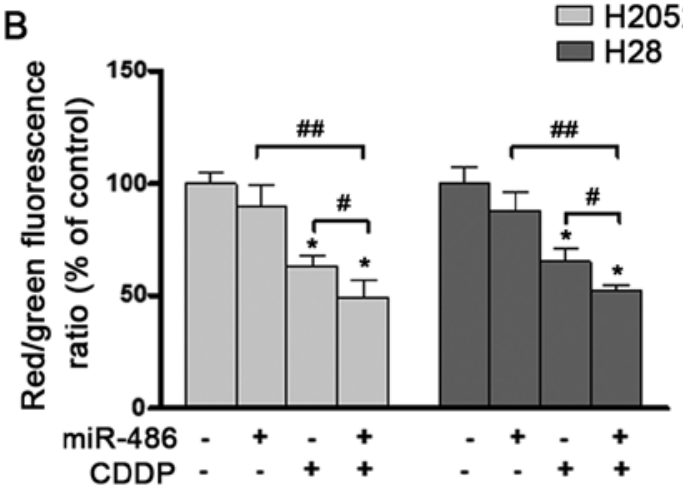

Figure 8. Combined effects of transfection and CDDP treatment. (A) Intracellular ROS levels and (B) mitochondrial membrane potential following transfection with miR-486 and/or treatment with CDDP in H2052 and H28 cells. Values refer to the control condition (miRNA control=100\%). Statistical significance is indicated vs. control $\left({ }^{*} \mathrm{P}<0.05 ;{ }^{* *} \mathrm{P}<0.01\right)$ and vs. the separate treatments $\left({ }^{\#} \mathrm{P}<0.05 ;{ }^{\# \#} \mathrm{P}<0.01\right)$. CDDP, cisplatin.

significantly suppressed cellular growth and cycle progression by targeting the cyclins and in particular, CDK4.

As CDK4 plays an important role in the G1/S phase transition, its deregulation is one of the most common alterations found in human cancers, including MPM. This checkpoint is crucial in cell survival, ensuring the detection and repair of genetic damage, as well as the prevention of uncontrolled cell division. The suppressive effects of miR-486 on $C D K 4$ have already been observed in oesophageal cancer (49) and NSCLC (48), leading to the conclusion that miR-486 may act as tumour suppressor. The 3'-UTR of $C D K 4$ is the direct interaction region between this miRNA and $C D K 4$ (48).

The antiproliferative effects of miR-486 on MPM cells are pivoted by the reduction in PIMI expression observed. In this rapidly growing invasive cancer, the role of PIM1 downregulation in the suppression of cell proliferation by cell arrest at the G0/G1 phase and of cell invasion and migration, has already been demonstrated, as well as the role of the inhibition of other miRNAs $(33,50)$. The negative correlation between miR-486 and PIM1 in cancer tissues and the miR-486/PIM1 axis has already been observed in lung cancer (35), breast cancer (34) and osteosarcoma (51). The present study confirmed this association in mesothelioma. Unlike what has been observed in lung cancer cells, in which the enforced expression of miR-486-5p resulted in a decrease in PIM1 protein expression not accompanied by a significant reduction in mRNA expression in cells, suggesting that miR-486 may inhibit its expression mainly through post-transcriptional regulation (35), in the present study, a parallel decrease in PIM1 mRNA and protein expression was observed.

Previous studies have confirmed that PIM1 plays a role in cellular proliferation by regulating cell cycle progression at multiple points and through various target proteins, and that its levels change with the stages of the cell cycle, related to the onset of DNA synthesis (32). This highly conserved protein is an unusual serine or threonine kinase, as it is constitutively active and may rightly be considered a cell survival factor. Its overexpression may contribute to cancer development by protecting cells from undergoing apoptosis induced by exposure to stress factors and drugs, by promoting cell proliferation and genomic instability $(52,53)$. The increased survival was found to be associated with the maintenance of mitochondrial transmembrane potential. In the absence or by the reduced levels of PIM1, not only do cells exhibit a reduced mitochondrial membrane potential, but they also exhibit an elevated production of harmful ROS $(31,32)$. Based on current knowledge, PIM1 overexpression was suggested to be employed as a reliable diagnostic marker for several types of tumours and, in some cases, as a prognostic indicator of clinical outcomes (54-56). On the other hand, this may be a promising therapeutic target in appropriately selected cancers with the overexpression of this protein $(30,57)$. This proposal is also supported by the finding that the elimination of PIMI activity has no apparent effect on normal cells and yet is 
lethal to overexpressing cancer cells, avoiding the detrimental side-effects of most conventional treatments $(32,57)$.

Another important result obtained by miR-486 transfection is the reduction in the levels of inflammatory markers, such as IL-6, and this is very beneficial. Inflammation and the immune response emerged as key players in driving MPM progression and represent promising therapeutic targets: Manipulations of the inflammatory tumour stroma have been suggested to render MPM susceptible to therapies that have shown relevant results in other solid and aggressive tumours (2,3). Previous studies have also provided the rationale for utilising anti-IL-6 therapeutics alongside standard chemotherapy in an attempt to prolong survival and alleviate symptoms commonly witnessed in this disease, such as cachexia, thrombocytosis and immunosuppression (58-63).

To date, the only systemic treatment approved and registered by the Food and Drug Administration and the European Medicines Agency is platinum-based chemotherapy; however, its use in the treatment of MPM mostly yields frustrating results and the average life expectancy is usually $<1$ year with a 5-year survival of $<5 \%$ (64-66). Acquired resistance to drugs is still a major clinical issue. A number of studies have indicated that several miRNAs, and even miR-486, act as chemo-resistance regulators, controlling the levels of drug resistance-related genes $(21,26,43)$. The data of the present study demonstrated this modulating function of miR-486, enhancing the inhibitory and apoptotic effects of CDDP, thus suggesting the potential therapeutic advantage of combined CDDP/miR-486 therapeutic protocols in human MPM.

Of note, the decrease in mitochondrial membrane potential and the enhancement of ROS production were additively promoted by the overexpression of miR-486 and CDDP treatment. By contrast, no additive effect was observed for the decreased expression of PIM1 due to miR-486 overexpression and CDDP treatment. When two stressful events, such as CDDP and miR-486 upregulation occur at the same time, a complex crosstalk may be established and responses to the stressors may be enhanced. This result seems to be independent of PIM1 hypo-regulation and to involve other processes controlling redox equilibrium. Due to its broad target recognition and to its ability to have multiple effects, miR-486 is more advantageous and preferable than molecules able only to inhibit the PIM1 activity. Regardless of the histopathological type or BAPl mutation, and despite some differences in the extent of the responses, no discrepant behaviours have been observed between the two lines differing in histology and BAP1 mutations: $\mathrm{H} 28$ (epithelioid, BAP1 null) and $\mathrm{H} 2052$ (sarcomatoid, BAP1 wild-type) (67). The main difference concerns drug resistance as epithelial H28 cells are more resistant to cisplatin than sarcomatoid $\mathrm{H} 2052$ cells, and this behaviour may be due to $B A P 1$ mutation, whose loss-of-function is strongly associated with epithelioid differentiation and may play a role in promoting survival and in influencing chemosensitivity (68).

The complex biology of MPM requires an appropriate combination of approaches to overcome the vastly disappointing responses to chemotherapy. The miR-486 pathway not only has the potential for a greater understanding of the MPM pathogenesis, but also for therapeutic intervention, as it was demonstrated to play a role in regulating, at the same time, multiple mechanisms that are involved in the development and progression of this disease. A treatment effectively targeting multiple pathways simultaneously would be a major advance. In cancer, such an approach should not only inhibit cell growth more effectively, but should also prevent the loss of drug efficacy, due to the common emergence of resistance acting on a single pathway.

\section{Acknowledgements}

Not applicable.

\section{Funding}

No funding was received.

\section{Availability of data and materials}

The datasets used and/or analysed during the current study are available from the corresponding author on reasonable request.

\section{Authors' contributions}

SP, RA and PM conceived the study, and planned and carried out the experiments. RA wrote the manuscript with support from SP, PM, GP and DP. DP, DC, MT, MC, MG and GP critically revised the manuscript for important intellectual content. All authors (SP, RA, DP, MC, GP, MT, MG, DC and PM) contributed to the interpretation of the results and revised critically the manuscript for important intellectual content. SP and PM confirm the authenticity of all the raw data. All authors have read and approved the final version of the manuscript.

\section{Ethics approval and consent to participate}

Not applicable.

\section{Patient consent for publication}

Not applicable.

\section{Competing interests}

All authors declare that they have no competing interests.

\section{References}

1. Roe OD and Stella GM: Malignant pleural mesothelioma: History, controversy and future of a manmade epidemic. Eur Respir Rev 24: 115-131, 2015.

2. Carbone M and Yang H: Mesothelioma: Recent highlights. Ann Transl Med 5: 238, 2017.

3. Abbott DM, Bortolotto C, Benvenuti S, Lancia A, Filippi AR and Stella GM: Malignant pleural mesothelioma: Genetic and microenviromental heterogeneity as an unexpected reading frame and therapeutic challenge. Cancers (Basel) 12: 1186, 2020.

4. Takagi A, Hirose A, Futakuchi M, Tsuda H and Kanno J: Dose-dependent mesothelioma induction by intraperitoneal administration of multi-wall carbon nanotubes in p53 heterozygous mice. Cancer Sci 103: 1440-1444, 2012.

5. Takagi A, Hirose A, Nishimura T, Fukumori N, Ogata A, Ohashi N, Kitajima S and Kanno J: Induction of mesothelioma in $\mathrm{p} 3^{+/-}$mouse by intraperitoneal application of multi-wall carbon nanotube. J Toxicol Sci 33: 105-116, 2008. 
6. Goodman JE, Nascarella MA and Valberg PA: Ionizing radiation: A risk factor for mesothelioma. Cancer Causes Control 20: 1237-1254, 2009.

7. Pershouse MA, Heivly S and Girtsman T: The role of SV40 in malignant mesothelioma and other human malignancies. Inhal Toxicol 18: 995-1000, 2006.

8. Bruno C, Tumino R, Fazzo L, Cascone G, Cernigliaro A, De Santis M, Giurdanella MC, Nicita C, Rollo PC, Scondotto S, et al: Incidence of pleural mesothelioma in a community exposed to fibres with fluoro-edenitic composition in Biancavilla (Sicily, Italy). Ann Ist Super Sanita 50: 111-118, 2014

9. Carbone M, Ly BH, Dodson RF, Pagano I, Morris PT, Dogan UA, Gazdar AF, Pass HI and Yang H: Malignant mesothelioma: Facts, myths, and hypotheses. J Cell Physiol 227: 44-58, 2012.

10. Xu LL, Yang Y, Wang Z, Wang XJ, Tong ZH and Shi HZ: Malignant pleural mesothelioma: Diagnostic value of medical thoracoscopy and long-term prognostic analysis. BMC Pulm Med 18: 56, 2018.

11. Zhang $\mathrm{W}, \mathrm{Wu} \mathrm{X}, \mathrm{Wu} \mathrm{L}, \mathrm{Zhang} \mathrm{W}$ and Zhao X: Advances in the diagnosis, treatment and prognosis of malignant pleural mesothelioma. Ann Transl Med 3: 182, 2015.

12. Bibby AC, Tsim S, Kanellakis N, Ball H, Talbot DC, Blyth KG, Maskell NA and Psallidas I: Malignant pleural mesothelioma: An update on investigation, diagnosis and treatment. Eur Respir Rev 25: 472-486, 2016.

13. Cao S, Jin S, Cao J, Shen J, Hu J, Che D, Pan B, Zhang J, He X, Ding $\mathrm{D}$, et al: Advances in malignant peritoneal mesothelioma. Int J Colorectal Dis 30: 1-10, 2015.

14. Slaby O, Laga R and Sedlacek O: Therapeutic targeting of non-coding RNAs in cancer. Biochem J 474: 4219-4251, 2017.

15. Lo Russo G, Tessari A, Capece M, Galli G, de Braud F, Garassino MC and Palmieri D: MicroRNAs for the diagnosis and management of malignant pleural mesothelioma: A literature review. Front Oncol 8: 650, 2018.

16. Tomasetti M, Gaetani S, Monaco F, Neuzil J and Santarelli L: Epigenetic Regulation of miRNA expression in malignant mesothelioma: MiRNAs as biomarkers of early diagnosis and therapy. Front Oncol 9: 1293, 2019.

17. Birnie KA, Prele CM, Thompson PJ, Badrian B and Mutsaers SE: Targeting microRNA to improve diagnostic and therapeutic approaches for malignant mesothelioma. Oncotarget 8 78193-78207, 2017.

18. Bartel DP: MicroRNAs: Target recognition and regulatory functions. Cell 136: 215-233, 2009

19. ElKhouly AM, Youness RA and Gad MZ: MicroRNA-486-5p and microRNA-486-3p: Multifaceted pleiotropic mediators in oncological and non-oncological conditions. Noncoding RNA Res 5: 11-21, 2020.

20. Huang XP, Hou J, Shen XY, Huang CY, Zhang XH, Xie YA and Luo XL: MicroRNA-486-5p, which is downregulated in hepatocellular carcinoma, suppresses tumor growth by targeting PIK3R1. FEBS J 282: 579-594, 2015.

21. Sun H, Cui C, Xiao F, Wang H, Xu J, Shi X, Yang Y, Zhang Q, Zheng X, Yang X, et al: MiR-486 regulates metastasis and chemosensitivity in hepatocellular carcinoma by targeting CLDN10 and CITRON. Hepatol Res 45: 1312-1322, 2015.

22. Zhu J, Zeng Y, Xu C, Qin H, Lei Z, Shen D, Liu Z and Huang JA: Expression profile analysis of microRNAs and downregulated miR-486-5p and miR-30a-5p in non-small cell lung cancer. Oncol Rep 34: 1779-1786, 2015.

23. Wang J, Tian X, Han R, Zhang X, Wang X, Shen H, Xue L, Liu Y, Yan X, Shen J, et al: Downregulation of miR-486-5p contributes to tumor progression and metastasis by targeting protumorigenic ARHGAP5 in lung cancer. Oncogene 33: 1181-1189, 2014.

24. Rask L, Balslev E, Sokilde R, Hogdall E, Flyger H, Eriksen J and Litman T: Differential expression of miR-139, miR-486 and miR-21 in breast cancer patients sub-classified according to lymph node status. Cell Oncol (Dordr) 37: 215-227, 2014.

25. Yi Y, Lu X, Chen J, Jiao C, Zhong J, Song Z, Yu X and Lin B: Downregulated miR-486-5p acts as a tumor suppressor in esophageal squamous cell carcinoma. Exp Ther Med 12: 3411-3416, 2016.

26. Wang W, Liu B, Sun S, Lan L, Chen Y, Han S, Li L and Li Z: Downregulation of miR-486-5p enhances the anti-tumor effect of 5-fluorouracil on pancreatic cancer cells. Onco Targets Ther 13: 1649-1659, 2020.

27. Jiang M, Li X, Quan X, Yang X, Zhaeng C, Hao X, Qu R and Zhou B: MiR-486 as an effective biomarker in cancer diagnosis and prognosis: A systematic review and meta-analysis. Oncotarget 9: 13948-13958, 2018.
28. Mozzoni P, Ampollini L, Goldoni M, Alinovi R, Tiseo M, Gnetti L, Carbognani P, Rusca M, Mutti A, Percesepe A and Corradi M: MicroRNA expression in malignant pleural mesothelioma and asbestosis: A pilot study. Dis Markers 2017: 9645940 , 2017.

29. Xiang X, Yuan D, Liu Y, Li J, Wen Q, Kong PY, Gao L, Zhang C, Peng X and Zhang X: PIM1 overexpression in T-cell lymphomas protects tumor cells from apoptosis and confers doxorubicin resistance by upregulating c-myc expression. Acta Biochim Biophys Sin (Shanghai) 50: 800-806, 2018.

30. Cao L, Wang F, Li S, Wang X, Huang D and Jiang R: PIM1 kinase promotes cell proliferation, metastasis and tumor growth of lung adenocarcinoma by potentiating the c-MET signaling pathway. Cancer Lett 444: 116-126, 2019.

31. Chauhan SS, Toth RK, Jensen CC, Casillas AL, Kashatus DF and Warfel NA: PIM kinases alter mitochondrial dynamics and chemosensitivity in lung cancer. Oncogene 39: 2597-2611, 2020.

32. Magnuson NS, Wang Z, Ding G and Reeves R: Why target PIM 1 for cancer diagnosis and treatment? Future Oncol 6: 1461-1478, 2010.

33. Mawas AS, Amatya VJ, Suzuki R, Kushitani K, Mohi El-Din MM and Takeshima Y: PIM1 knockdown inhibits cell proliferation and invasion of mesothelioma cells. Int J Oncol 50: 1029-1034, 2017.

34. Zhang G, Liu Z, Cui G, Wang X and Yang Z: MicroRNA-486-5p targeting PIM-1 suppresses cell proliferation in breast cancer cells. Tumour Biol 35: 11137-11145, 2014

35. Pang W, Tian X, Bai F, Han R, Wang J, Shen H, Zhang X, Liu Y, Yan X, Jiang F and Xing L: Pim-1 kinase is a target of miR-486-5p and eukaryotic translation initiation factor $4 \mathrm{E}$, and plays a critical role in lung cancer. Mol Cancer 13: 240, 2014

36. Jin X, Pang W, Zhang Q and Huang H: MicroRNA-486-5p improves nonsmall-cell lung cancer chemotherapy sensitivity and inhibits epithelial-mesenchymal transition by targeting twinfilin actin binding protein 1. J Int Med Res 47: 3745-3756, 2019.

37. Blower PE, Chung JH, Verducci JS, Lin S, Park JK, Dai Z, Liu CG, Schmittgen TD, Reinhold WC, Croce CM, et al: MicroRNAs modulate the chemosensitivity of tumor cells. Mol Cancer Ther 7: 1-9, 2008.

38. Salimian J, Baradaran B, Azimzadeh Jamalkandi S, Moridikia A and Ahmadi A: MiR-486-5p enhances cisplatin sensitivity of human muscle-invasive bladder cancer cells by induction of apoptosis and down-regulation of metastatic genes. Urol Oncol 38: 738.e9-738.e21, 2020.

39. Livak KJ and Schmittgen TD: Analysis of relative gene expression data using real-time quantitative PCR and the 2(-Delta Delta C(T)) Method. Methods 25: 402-408, 2001.

40. Sturchio E, Berardinelli MG, Boccia P, Zanellato $M$ and Gioiosa S: MicroRNAs diagnostic and prognostic value as predictive markers for malignant mesothelioma. Arch Environ Occup Health 75: 471-482, 2020.

41. Reid G, Kao SC, Pavlakis N, Brahmbhatt H, MacDiarmid J, Clarke S, Boyer M and van Zandwijk N: Clinical development of TargomiRs, a miRNA mimic-based treatment for patients with recurrent thoracic cancer. Epigenomics 8: 1079-1085, 2016.

42. Reid G, Johnson TG and van Zandwijk N: Manipulating microRNAs for the treatment of malignant pleural mesothelioma: Past, present and future. Front Oncol 10: 105, 2020.

43. Seo HA, Moeng S, Sim S, Kuh HJ, Choi SY and Park JK: MicroRNA-Based Combinatorial cancer therapy: Effects of MicroRNAs on the efficacy of anti-cancer therapies. Cells 9: 29, 2019.

44. Fu H, Tie Y, Xu C, Zhang Z, Zhu J, Shi Y, Jiang H, Sun Z and Zheng X: Identification of human fetal liver miRNAs by a novel method. FEBS Lett 579: 3849-3854, 2005.

45. Small EM, O'Rourke JR, Moresi V, Sutherland LB, McAnally J, Gerard RD, Richardson JA and Olson EN: Regulation of PI3-kinase/Akt signaling by muscle-enriched microRNA-486. Proc Natl Acad Sci USA 107: 4218-4223, 2010

46. Mees ST, Mardin WA, Sielker S, Willscher E, Senninger N, Schleicher C, Colombo-Benkmann $\mathrm{M}$ and Haier J: Involvement of CD40 targeting miR-224 and miR-486 on the progression of pancreatic ductal adenocarcinomas. Ann Surg Oncol 16: 2339-2350, 2009

47. He M, Wang G, Jiang L, Qiu C, Li B, Wang J and Fu Y: MiR-486 suppresses the development of osteosarcoma by regulating PKC- $\delta$ pathway. Int J Oncol 50: 1590-1600, 2017.

48. Shao Y, Shen YQ, Li YL, Liang C, Zhang BJ, Lu SD, He YY, Wang P, Sun QL, Jin YX and Ma ZL: Direct repression of the oncogene CDK4 by the tumor suppressor miR-486-5p in non-small cell lung cancer. Oncotarget 7: 34011-34021, 2016. 
49. Lang B and Zhao S: MiR-486 functions as a tumor suppressor in esophageal cancer by targeting CDK4/BCAS2. Oncol Rep 39: 71-80, 2018.

50. Amatya VJ, Mawas AS, Kushitani K, Mohi El-Din MM and Takeshima Y: Differential microRNA expression profiling of mesothelioma and expression analysis of miR-1 and miR-214 in mesothelioma. Int J Oncol 48: 1599-1607, 2016.

51. Liu Y, Zhang J, Xing C, Wei S, Guo N and Wang Y: MiR-486 inhibited osteosarcoma cells invasion and epithelial-mesenchymal transition by targeting PIM1. Cancer Biomark 23: 269-277, 2018.

52. Zhang X, Song M, Kundu JK, Lee MH and Liu ZZ: PIM Kinase as an executional target in cancer. J Cancer Prev 23: 109-116, 2018.

53. Zhao W, Qiu R, Li P and Yang J: PIM1: A promising target in patients with triple-negative breast cancer. Med Oncol 34: 142, 2017.

54. Chen J and Tang G: PIM-1 kinase: A potential biomarker of triple-negative breast cancer. Onco Targets Ther 12: 6267-6273, 2019.

55. Yang H, He K, Dong W, Fang J, Zhong S, Tang L and Long L: PIM-1 may function as an oncogene in cervical cancer via activating the EGFR signaling. Int J Biol Markers 35: 67-73, 2020

56. Xu J, Xiong G, Cao Z, Huang H, Wang T, You L, Zhou L, Zheng L, Hu Y, Zhang T and Zhao Y: PIM-1 contributes to the malignancy of pancreatic cancer and displays diagnostic and prognostic value. J Exp Clin Cancer Res 35: 133, 2016.

57. Asati V, Mahapatra DK and Bharti SK: PIM kinase inhibitors: Structural and pharmacological perspectives. Eur J Med Chem 172: 95-108, 2019.

58. Abdul Rahim SN, Ho GY and Coward JI: The role of interleukin-6 in malignant mesothelioma. Transl Lung Cancer Res 4: 55-66, 2015.

59. Donnenberg AD, Luketic JD and Donnenberg VS: Secretome of pleural effusions associated with non-small cell lung cancer (NSCLC) and malignant mesothelioma: Therapeutic implications. Oncotarget 10: 6456-6465, 2019.

60. Nakano T, Chahinian AP, Shinjo M, Tonomura A, Miyake M, Togawa N, Ninomiya K and Higashino K: Interleukin 6 and its relationship to clinical parameters in patients with malignant pleural mesothelioma. Br J Cancer 77: 907-912, 1998.
61. Acencio MM, Soares B, Marchi E, Silva CS, Teixeira LR and Broaddus VC: Inflammatory cytokines contribute to asbestos-induced injury of mesothelial cells. Lung 193: 831-837, 2015.

62. Topley N, Jörres A, Luttmann W, Petersen MM, Lang MJ, Thierauch KH, Müller C, Coles GA, Davies M and Williams JD: Human peritoneal mesothelial cells synthesize interleukin-6: Induction by IL-1 beta and TNF alpha. Kidney Int 43: 226-233, 1993.

63. Adachi Y, Aoki C, Yoshio-Hoshino N, Takayama K, Curiel DT and Nishimoto N: Interleukin-6 induces both cell growth and VEGF production in malignant mesotheliomas. Int J Cancer 119: 1303-1311, 2006

64. Norbet C, Joseph A, Rossi SS, Bhalla S and Gutierrez FR: Asbestos-related lung disease: A pictorial review. Curr Probl Diagn Radiol 44: 371-382, 2015.

65. Hiddinga BI, Rolfo C and van Meerbeeck JP: Mesothelioma treatment: Are we on target? A review. J Adv Res 6: 319-330, 2015.

66. Nicolini F, Bocchini M, Bronte G, Delmonte A, Guidoboni M, CrinO L and Mazz M: Malignant pleural mesothelioma: State-of-the-Art on current therapies and promises for the future. Front Oncol 9: 1519, 2020.

67. Sacco JJ, Kenyani J, Butt Z, Carter R, Chew HY, Cheeseman LP, Darling S, Denny M, Urbe S, Clague MJ and Coulson JM: Loss of the deubiquitylase BAP1 alters class I histone deacetylase expression and sensitivity of mesothelioma cells to HDAC inhibitors. Oncotarget 6: 13757-13771, 2015.

68. Guazzelli A, Meysami P, Bakker E, Demonacos C, Giordano A, Krstic-Demonacos M and Mutti L: BAP1 status determines the sensitivity of malignant mesothelioma cells to gemcitabine treatment. Int J Mol Sci 20: 429, 2019.

This work is licensed under a Creative Commons Attribution-NonCommercial-NoDerivatives 4.0 International (CC BY-NC-ND 4.0) License. 